Received: 29/07/2018

Revision: 17/11/2018

Accepted: 20/11/2018

OnlineFirst: 23/11/2018

\title{
Enhancing Pilot's Aviation English Learning, Attitude and Motivation through the Application of Content and Language Integrated Learning
}

\section{Parvin Karimi}

Faculty of English Language Department, Islamic Azad University Isfahan (Khorasgan Branch). Isfahan, Iran, parvinkarimi50@yahoo.com

\author{
Ahmad Reza Lotfi \\ Asst. Prof., Faculty of English Language Department, Islamic Azad University Isfahan \\ (Khorasgan Branch). Isfahan, Iran, lotfi.ahmadreza@gmail.com
}

\section{Reza Biria}

Assoc. Prof., Faculty of English Language Department, Islamic Azad University Isfahan (Khorasgan Branch). Isfahan, Iran, biria_reza@yahoo.com

The present study sought to investigate the effectiveness of Content and Language Integrated Learning (CLIL) in enhancing Iranian aviation students' attitude and motivation in dealing with the highly specialized features of aviation English. To this end, 40 pilots studying at Mahan air in Tehran were randomly placed in the experimental $(n=20)$ and control $(n=20)$ groups. The study followed a pretestposttest experimental design. The experimental group received instruction through CLIL. The control group were taught by a traditional approach. The analysis revealed that the experimental group performed better than the control group on the posttest. Interestingly the experimental group were highly motivated and had a positive perception about the effectiveness of CLIL activities that led them to be experienced in higher achievement of the language learning outcomes. Notably, the findings of the study suggest some important implications for course designers, and teachers who work in the area of teaching English for Occupational Purposes (EOP).

Keywords: aviation English, CLIL, EOP, motivation, perception

\section{INTRODUCTION}

From the number of languages spoken worldwide, English has been selected as the language of technology and science. This thus motivates non-native scientists and researchers to learn the language to have access to different references and documents

Citation: Karimi, P., Lotfi, A. R., \& Biria, R. (2019). Enhancing Pilot's Aviation English Learning, Attitude and Motivation through the Application of Content and Language Integrated Learning. International Journal of Instruction, 12(1), 751-766. https://doi.org/10.29333/iji.2019.12148a 
influencing their careers. Consequently, attempts to design the most efficient ways of learning and teaching English to different groups of learners have gained a considerable momentum in recent years. In particular, teaching English for specialized purposes at higher educational levels plays a pivotal role in tertiary levels of education. The need for a wide variety of professional language programs categorized under the umbrella term "English for specific purposes" is being felt more than ever before. ESP relates to a wide range of areas such as industry, vocational training, and commercial sectors. It is goal- oriented and based on English needs and needs analysis in the profession. ESP pays attention to the language skills and vocabulary in certain areas (Gavrilova \& Trostina, 2014).

Notably, the integration of subject- matter content and language learning (CLIL) has been regarded as one of the most significant views concerning the appropriate methodology required for teaching English for specific purposes. The evidential bases offered by various studies reflect that both content and language receive attention simultaneously by using CLIL because the learning of the content is integrated with that of the language. Such integration can significantly improve language performance without resorting to additional teaching efforts. According to Marsh (2000), the pedagogical effectiveness of CLIL depends largely on the exploitation of both content and language learning at the same time. The main reason is that CLIL activates different crucial factors such as learner engagement, motivation, and active participation which ultimately result in language learning. As Al-Hoorie (2016) stated, learners are rational individuals whose progress depends on the powerful influence of motivational factors in modern language teaching contexts.

Globally, the academic aviation programs implemented around the world choose the English language as it is the official and standardized language of aviation communication because most aircraft and airlines manuals, pilot's documentation, flight plans, and airports traffic controls are written in the English language. As a result, the main objective of the present study was to investigate how implementing CLIL increases learners' language proficiency, perception, and motivation in their learning of the prespecified outcomes compared to other traditional, non- CLIL approaches.

\section{LITERATURE REVIEW}

Inspired by the Canadian immersion program and the United States content-based instruction, CLIL has been used as an educational approach to foreign language teaching whereby linguistic forms are learnt indirectly through non-linguistic content (Eurydice, 2006; Marsh, 2002). In other words, CLIL is an umbrella term refers to any activity in learning of non-language subject in which a particular subject content serves as a medium for the learning of foreign language items. Nikula (2017) expressed that CLIL is used especially in Europe for bilingual education where a foreign language, in most cases English, is used as the language of instruction in non-language school subjects. CLIL class provides a context for meaningful language use and leads to language learning besides content learning, CLIL is an important instrument to make European citizens' bi- and multilingualism, to be offered and create alongside with subject matter learning, and regular foreign language teaching for students in mainstream education. 
Based on Wolff (2009), CLIL is widely accepted in Europe and commonly used for teaching the content subject through a foreign language. CLIL allows pupils to use language in a different way, and in complex ways; therefore, the pupils will have a better comprehension of the subject matter. Lorenzo, Casal, and Moore (2009) declared that CLIL learners have higher linguistic competence, which shows an obvious benefit of CLIL due to a higher exposure to a foreign language. CLIL promotes meaningful interaction and creativity. It is a more successful way of second language acquisition as it is learned for immediate use and for a real purpose. Goris (2009) stated that CLIL is different from the communicative approach because learners use language in content as an authentic setting, and does not have to simulate real-life situations, however, this reality will increase learners' interaction and motivation during the class time. Interaction is a fundamental need for learning to take place. Through communication and interaction, students practice their language skills and discuss the content to which they are exposed. Thus it makes the students be so active and motivated to work harder. Ruiz de Zarob (2008) compared the speaking skills of non- CLIL and CLIL students in Spain. After the speech production test, the results showed that CLIL students' performance showed higher linguistic level and greater lexical richness. Dalton-Puffer, Huttner, Schindelegger, and Smit (2009) conducted a research in Austrian vocational colleges and investigated CLIL students' perception about the teaching approach. They found the course useful and the teacher allowed them for more equally and diversity in the teacher-student relationship in the classroom. Both teacher and students were responsible for the learning process.

Alternatively, motivation is a driving force determining why someone chooses to do something. Moreover, Motivation is one of the most important factors in learning. Motivation is a basic component of human performance and learning. Accordingly, Gardner (2010) stated that motivation is difficult to explain. He expressed that motivation is a factor that motivated individuals display. There are different kinds of motivation ranging from internal and external factors which influence learning. As an illustration, learners' curiosity and interest are related to the internal factor while environmental factors are regarded as an external factor of motivation. Stansfield and Winke (2008) noted that high motivation causes a person to spend much time and to use more strategies on task which relates to the learner's aptitude and increases his potential. Moreover, Gardner and Lambert (1972) defined instrumental and integrative motivation. There are different factors that influence second language (L2) learning. However, learner's motivation and desire to learn a particular language is often singled out as the most significant factor in the overall process for language acquisition. Being motivated is one of the most important factors in learning a foreign language (Abdelrahim \& Humaida, 2012). Furthermore, based on Gardner (2010), instrumental motivation in language learning is related to the time when an individual tries to learn another language for some practical gain not for the social implications. It can be stated that when a person learns a language with non-interpersonal purposes such as to pass an exam or just to have a career, it is related to instrumental motivation. Therefore, students with an instrumental motivation are going to learn a language because of a practical reason such as getting a job or getting into college. On the other hand, the integrative 
motivation is a key factor in assisting the learners to improve some level of proficiency in the language learning, when he becomes a resident in a new place/society and environment that uses the target language in its social interaction. As Finegan (1999, p.568) posited, students as one of the members of the learning community are naturally under the influence of integrative motivation which "typically provides successful acquisition of a native-like pronunciation and a wide range of registers". Another classification of motivation consists of intrinsic and extrinsic. Intrinsic motivation is in the inner of the learners. A student who is intrinsically motivated wants to study and learn because he finds the material interesting, they thus receive some kind of satisfaction from their learning. On the other hand, if a person places the responsibility on others and on circumstances outside self, he has an external locus of control (Dornyei, 2000), which relates to extrinsic motivation. Indeed, extrinsic motivation relates to motivation that comes from outside of an individual; its factors are outsider or external rewards such as money or grads which provides pleasure and satisfaction that the task itself may not provide (Dornyei, 2000). More generally, if an L2 student engages with the L2 culture, the intrinsic motivation can turn out to be an integrative motivation. If the L2 student wishes to gain aims using L2, the intrinsic motivation can also turn out to be the instrumental motivation. These two forms of motivation, extrinsic and intrinsic are pertinent to instrumental and integrative motivation related to L2 learning (Brown, 2000).

In a study, Bernaus and Gardner (2008) investigated the effects of teacher's strategies on the learners' perceptions in Catalonia, Spain. The result indicated that positive students' attitudes and their integrative motivation toward the learning situation were positive factors of English achievement that enhance learning.

Researchers have expressed different views toward different kinds of motivation. According to Lucas (2010), learners are intrinsically motivated to learn speaking and reading skills and are also intrinsically motivated by knowledge and achievement. Tuan (2012) studied the effect of EFL learner's motivation on their English learning. She used a questionnaire as an instrument for collecting data. Both teachers and students were involved in this survey. The findings of the research showed that the learners had positive motivation toward learning of foreign language. In another study, Mao (2011) carried out a research on L2 motivation and application in reading class in senior high school to examine the effect of motivation on learning. In his study, the instrument was a questionnaire to collect the data. The results showed that combination of integrative motivation and instrumental motivation can influence reading improvement. Furthermore, teachers should take some effective application to increase student's motivation during the class and help them develop integrative motivation towards English learning.

Due to the significance of affective filter, the optimum learning occurs in an environment of high stimulation and low anxiety. Therefore, the emotional state of the learner acting as a filter may pass or impede input needed for L2 acquisition. Many ESL learners come to class with uncertainty because they often feel that they are separated from their native cultures and fight to adapt to certain disturbances evoked by the new 
situation. Surprisingly, such disturbances can be monitored and even overcome with the help of CLIL. In a study, Doiz, Lasagabaster and Sierra (2014) expressed in their analyses that students in CLIL setting were more motivated than the control group in the study.

On this basis, the present study investigated how CLIL can enhance the Iranian aviation students' attitude and motivation and L2 learning and thus answer the following research question:

RQ: Does the implementation of CLIL have an effect on aviation students' attitude and motivation towards English language learning?

\section{METHOD}

\section{Design and Context of the Study}

This study employed a pretest-posttest experimental design. The researcher selected two classes that were subsequently assigned to two groups randomly: experimental and control. The research was conducted at Mahan Airlines headquarters training center in winter of 2016, in Tehran, Iran.

Pilot students were studying the international book named Private Pilot Manual (PPM) as their reference book. The PPM was written in English. The PPM included different parts such as aircraft weight and balance (W\&B), meteorology for pilots, interpreting weather data, and radio navigation systems. All were in English and contained aviation special concepts and terminology.

Aircraft W\&B course instructs delegates in the principles of aircraft weight and balance according to the industry standard IATA design manual and automated load sheet. During this class, the learners learn about the maximum landing weight, aircraft central gravity, basic empty weight, standard weight of fuel, and maximum take-off weight. The course would be implemented in 30 hours, six sessions, and every session 5 hours.

\section{Population and Sample}

Forty male pilots (20 to 30 years old) were randomly placed in the experimental $(n=20)$ and control $(n=20)$ groups. Regarding their English language proficiency according to the ICAO regulations, students attending the private pilot license (PPL) should pass an entrance exam before attending the course which was based on Oxford Placemat Test (OPT). To select the PPL applicants, the training department had administered the OPT test to them before starting the course. Those who score more than 75 could register for the class. Therefore, the participants of the study were homogenous in terms of English language proficiency. The attending instructors in CLIL served as the subject matter teacher for the first 45 minutes of the class and the EFL teacher for the second 45 minutes whereas in the non-CLIL class, only a subject matter teacher was presented during the course.

\section{Instruments}

In this study 3 instruments were employed for data collection. The required data would be collected through, pretest, questionnaire, and posttest. 
The first instrument, pretest, was related to their language and content knowledge of the learners under the study. It should be stated that the researcher adopted the pretest as the posttest in order to evaluate language and content knowledge before and after the treatment. For the second data collection, researcher utilized questionnaire to reveal the findings of participants' attitude and motivation for English leaning during the course. The structures of the questionnaires were as follows:

The questionnaire consisted of 30 items which was developed based on Gardner Attitude \& Motivation Test Battery. Item 1 to 15 were designed to elicit information and responses dealing with students' attitudes toward language learning and situation, and item 16 to 30 were related to their motivation in language learning during the course. Questionnaire, including five-point Likert scale, ranging from "strongly disagree $=1$ " to "strongly agree $=5$ ".

The third instrument, posttest, was related to their language and content learning outcomes due to motivation in CLIL and non-CLIL classes under the study. It should be stated that the researcher adopted the posttest as an instrument in order to evaluate language and content learning; in view of the fact that all the questions were about the content matter and in English. The pretest and posttest was based on the ICAO standard question booklet which contained 30 multiple choice questions with the total scores of 60 to measure content learning, and also an oral exam with a score of 40 to evaluate language knowledge, those who scored 70 and above would pass the course.

\section{Data Collection Procedure}

The researcher started to collect data after the participants began their W\&B course. On the first session of the class, the pretest was administered to the participants to examine their knowledge on understanding the questions and content in the English language. The second step for data collection in this study was designing and piloting a questionnaire. The respondents were required to rate each item on the basis of 5point Likert Scale. To design the questionnaire, the items were carefully selected and the opinion of a senior researcher was also considered. The initial version of the questionnaire was subjected to a pilot study in order to detect shortcomings, redundancy, remove irrelevant items, and check the reliability. Cronbach's alpha reliability of the questionnaire was 0.82 that indicated an acceptable level of consistency. The final version of the questionnaire was given to the participants to examine their attitudes and motivation. In the last week of the course all 40 participants completed the questionnaire in 30 minutes. The Likert-scale questionnaire was analyzed using Statistical Package for the Social Sciences (SPSS).

Two days after the last session of the W\&B course, the posttest was administered. The written part (multiple choice items) of the posttest for both groups was administered by the training staff without the teachers being present at the session. In addition, an oral exam was performed in the same day afternoon by 3 teachers based on ICAO booklet materials. This exam was performed in English to test language learning outcome. The teachers graded the students' oral performance on different aspects: grammar, 
vocabulary, pronunciation, and fluency. They gave 1 to 10 score for each aspect. The scores obtained from oral exam were used to measure posttest result.

Two days after the exams, the teachers reported the students' scores to the training department. The participants who scored 70 or above would attend the next course in the following week. The participants' scores provided important information about their progress and improvement during that special course.

\section{FINDINGS}

The data collected through this study were analyzed using independent-samples t-test which has two main assumptions; normality of the data and homogeneity of variances of the groups. As displayed in Table 1, the absolute values of the ratios of skewness and kurtosis over their standard errors were lower than 1.96 , which shows normality of the data.

Table 1

Descriptive statistics; testing normality of data

\begin{tabular}{|c|c|c|c|c|c|c|c|c|}
\hline \multirow[t]{2}{*}{ Group } & & \multirow{2}{*}{$\frac{\mathrm{n}}{\text { Statistic }}$} & \multicolumn{3}{|c|}{ Skewness } & \multicolumn{3}{|c|}{ Kurtosis } \\
\hline & & & Statistic & Std. Error & Ratio & Statistic & Std. Error & Ratio \\
\hline \multirow[t]{4}{*}{ CLIL } & Pretest & 20 & .002 & .512 & .003 & -.974 & .992 & -0.98 \\
\hline & Posttest & 20 & -.419 & .512 & -0.82 & -.250 & .992 & -0.25 \\
\hline & Attitude & 20 & -.041 & .512 & -0.08 & .116 & .992 & 0.12 \\
\hline & Motivation & 20 & .805 & .512 & 1.57 & .730 & .992 & 0.74 \\
\hline \multirow[t]{4}{*}{ Non-CLIL } & Pretest & 20 & -.175 & .512 & -0.34 & -.769 & .992 & -0.77 \\
\hline & Posttest & 20 & .718 & .512 & 1.40 & -.469 & .992 & -0.47 \\
\hline & Attitude & 20 & .514 & .512 & 1.00 & .699 & .992 & 0.70 \\
\hline & Motivation & 20 & .142 & .512 & 0.28 & -.105 & .992 & -0.11 \\
\hline
\end{tabular}

\section{Reliability of Instruments}

Table 2 and Table 3 display the reliability indices for the pretest and posttest, and attitude and motivation questionnaires. The KR-21 reliability index for the pretest and posttest of CLIL test were .74 and .87 , respectively.

Table 2

Descriptive statistics and KR-21 reliability of test

\begin{tabular}{lccccccc}
\hline & $\mathrm{N}$ & Minimum & Maximum & $M$ & $S D$ & Variance & KR-21 \\
\hline CLIL & 40 & 45 & 80 & 64.35 & 9.234 & 85.259 & .74 \\
Posttest & 40 & 70 & 100 & 87.18 & 9.052 & 81.943 & .87 \\
\hline
\end{tabular}

The Cronbach's alpha for the questionnaire are displayed in Table 3. The reliability indices for the attitude and motivation sub-sections were .71 and .78 . The overall questionnaire had a reliability of .82 .

Table 3

Cronbach's alpha reliability of attitude and motivation

\begin{tabular}{lcc}
\hline & Cronbach's Alpha & $\mathrm{N}$ of Items \\
\hline Attitude & .715 & 15 \\
\hline Motivation & .787 & 15 \\
\hline Total & .825 & 30 \\
\hline
\end{tabular}




\section{Criterion Referenced Validity}

The correlation coefficients between the OPT and pretest and posttest were computed as the criterion referenced validity of the latter two tests. The results displayed in Table 4 indicated that the pretest $(\mathrm{r}(38)=.611$ representing a large effect size, $p=.000)$ and posttest $(\mathrm{r}(38)=.628$ representing a large effect size, $p=.000)$ enjoyed significant criterion referenced validity indices.

Table 4

Pearson Correlations; Criterion Referenced Validity

\begin{tabular}{lll}
\hline & & OPT \\
\hline \multirow{3}{*}{ Pretest } & Pearson Correlation & $.611^{* * *}$ \\
& Sig. (2-tailed) & .000 \\
& $\mathrm{~N}$ & 40 \\
\hline \multirow{3}{*}{ posttest } & Pearson Correlation & $.628^{* * *}$ \\
& Sig. (2-tailed) & .000 \\
& $\mathrm{~N}$ & 40 \\
\hline
\end{tabular}

${ }^{* *}$. Correlation is significant at the 0.01 level (2-

tailed).

\section{Homogenizing Groups on Pretest}

An independent t-test was run to compare the CLIL and non-CLIL groups' means on the pretest. Based on the results displayed in Table 5, the CLIL $(M=64.85, S D=9.31)$ and non-CLIL $(M=63.85, S D=9.36)$ groups had fairly close means on the pretest.

Table 5

Descriptive statistics; pretest

\begin{tabular}{llcccc}
\hline & Group & $\mathrm{n}$ & $M$ & $S D$ & Std. Error Mean \\
\hline Pret & CLIL & 20 & 64.85 & 9.315 & 2.083 \\
est & Non-CLIL & 20 & 63.85 & 9.366 & 2.094 \\
\hline
\end{tabular}

The results of the independent $\mathrm{t}$-test $(\mathrm{t}(29)=.339,95 \%$ CI [-4.97, 6.97], $p=.737, \mathrm{r}=$ .055 representing a weak effect size) (Table 6) indicated that the groups were homogenous in terms of their language and content knowledge as measured through the pretest.

It should be noted that the assumption of homogeneity of variances was met (Levene's F $=.001, p=1.00$ ). That is why the first row of Table 6, i.e. "Equal variances not assumed" was reported. 
Table 6

Independent samples t-test; Pretest by groups

\begin{tabular}{|c|c|c|c|c|c|c|c|c|c|}
\hline & \multicolumn{5}{|c|}{$\begin{array}{c}\text { Levene's Test for } \\
\text { Equality of Variances } \\
\end{array}$} & \multicolumn{4}{|c|}{ t-test for Equality of Means } \\
\hline & \multirow[t]{2}{*}{$\mathrm{F}$} & \multirow[t]{2}{*}{ Sig. } & \multirow[t]{2}{*}{$\mathrm{t}$} & \multirow[t]{2}{*}{ df } & \multirow[t]{2}{*}{$\begin{array}{l}\text { Sig. (2- } \\
\text { tailed) }\end{array}$} & \multirow[t]{2}{*}{$\begin{array}{l}\text { Mean } \\
\text { Difference }\end{array}$} & \multirow[t]{2}{*}{$\begin{array}{l}\text { Std. Error } \\
\text { Difference }\end{array}$} & \multicolumn{2}{|c|}{$\begin{array}{l}\text { 95\% Confidence } \\
\text { Interval of the } \\
\text { Difference }\end{array}$} \\
\hline & & & & & & & & Lower & Upper \\
\hline $\begin{array}{l}\text { Equal variances } \\
\text { assumed }\end{array}$ & .001 & 1.000 & .339 & 38 & .737 & 1.000 & 2.954 & -4.979 & 6.979 \\
\hline $\begin{array}{l}\text { Equal variances } \\
\text { not assumed }\end{array}$ & & & .339 & 37.999 & .737 & 1.000 & 2.954 & -4.979 & 6.979 \\
\hline
\end{tabular}

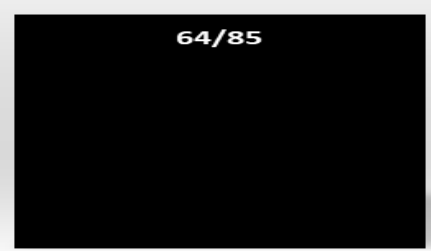

CLIL

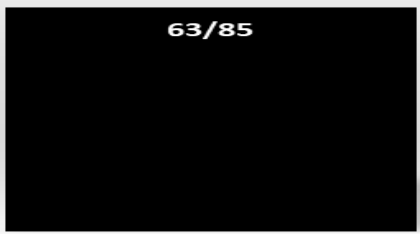

Non-CLIL

Figure 1

Means on pretest by groups

\section{Comparing Groups' Means on Posttest}

An independent t-test was run to compare the CLIL and non-CLIL groups' means on the posttest. Based on the results displayed in Table 7, the CLIL group $(M=94, S D=3.97)$ had a higher mean than the non-CLIL group $(M=80.35, S D=7.37)$ on the posttest.

Table7

Descriptive statistics; posttest by groups

\begin{tabular}{llllll}
\hline & Group & $\mathrm{n}$ & $M$ & $S D$ & Std. Error Mean \\
\hline \multirow{2}{*}{ CLIL } & CLIL & 20 & 94.00 & 3.974 & .889 \\
& Non-CLIL & 20 & 80.35 & 7.372 & 1.648 \\
\hline
\end{tabular}

The results of the independent $\mathrm{t}$-test $(\mathrm{t}(29)=7.28,95 \% \mathrm{CI}[9.82,17.47], p=.000, \mathrm{r}=$ .804 representing a large effect size) (Table 7) indicated that the CLIL significantly outperformed the non-CLIL group on the posttest. Thus the null-hypothesis was rejected. The CLIL method significantly enhanced the Aviation English learning of Iranian pilots through the application of content and language integrated learning.

It should be noted that the assumption of homogeneity of variances was not met (Levene's $\mathrm{F}=5.33, p=.026$ ). That is why the second row of Table 8, i.e. "Equal variances not assumed" was reported. 
Table 8

Independent samples t-test; posttest

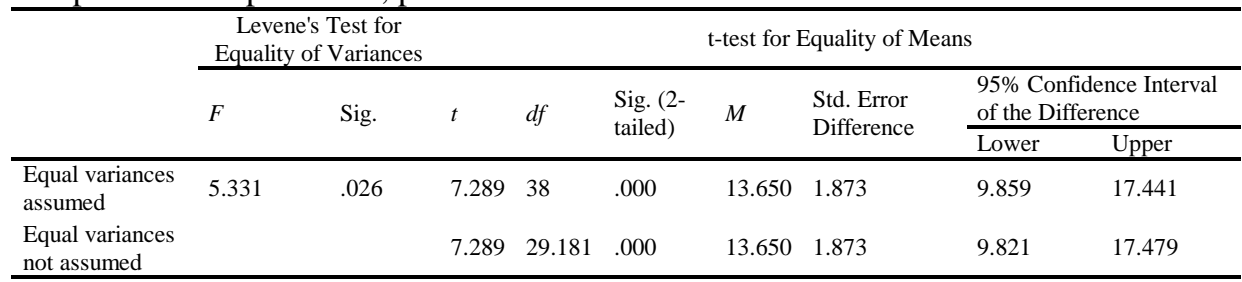

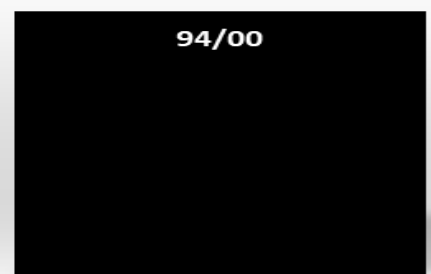

CLIL

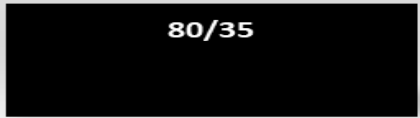

Non-CLIL

Figure 2

Means on posttest by groups

\section{Comparing Groups' Attitude towards Language Learning}

An independent t-test was run to compare the CLIL and non-CLIL groups' attitude towards language learning. Based on the results displayed in Table 9 it can be claimed that the CLIL group $(M=40.60, S D=5.25)$ showed a more positive attitude towards language learning than the non-CLIL group $(M=31.70, S D=4.95)$.

Table 9

Descriptive statistics; attitude towards language learning

\begin{tabular}{llcccc}
\hline & Group & $\mathrm{n}$ & $M$ & $S D$ & Std. Error Mean \\
\hline \multirow{2}{*}{ Attitude } & CLIL & 20 & 40.60 & 5.256 & 1.175 \\
& Non-CLIL & 20 & 31.70 & 4.953 & 1.108 \\
\hline
\end{tabular}

The results of the independent $\mathrm{t}$-test $(\mathrm{t}(38)=5.51,95 \%$ CI $[5.63,12.16], p=.000, \mathrm{r}=$ .666 representing a large effect size) (Table 10) indicated that the CLIL significantly had a more positive attitude towards language learning than the non-CLIL group. Thus the null-hypothesis was rejected.

It should be noted that the assumption of homogeneity of variances was retained (Levene's $\mathrm{F}=.109, p=.743$ ). That is why the first row of Table 10, i.e. "Equal variances assumed" was reported. 
Table 10

Independent samples t-test; attitude towards class by groups

\begin{tabular}{|c|c|c|c|c|c|c|c|c|c|}
\hline & \multicolumn{2}{|c|}{$\begin{array}{c}\text { Levene's Test for } \\
\text { Equality of Variances }\end{array}$} & \multicolumn{7}{|c|}{ t-test for Equality of Means } \\
\hline & \multirow[t]{2}{*}{ F } & \multirow[t]{2}{*}{ Sig. } & \multirow[t]{2}{*}{$t$} & \multirow[t]{2}{*}{$d f$} & \multirow{2}{*}{$\begin{array}{l}\text { Sig. (2- } \\
\text { tailed) }\end{array}$} & \multirow[t]{2}{*}{$M$} & \multirow{2}{*}{$\begin{array}{l}\text { Std. Error } \\
\text { Difference }\end{array}$} & \multicolumn{2}{|c|}{$\begin{array}{l}\text { 95\% Confidence Interva } \\
\text { of the Difference }\end{array}$} \\
\hline & & & & & & & & Lower & Upper \\
\hline $\begin{array}{l}\text { Equal variances } \\
\text { assumed }\end{array}$ & .109 & .743 & 5.511 & 38 & .000 & 8.900 & 1.615 & 5.631 & 12.169 \\
\hline $\begin{array}{l}\text { Equal variances } \\
\text { not assumed }\end{array}$ & & & 5.511 & 37.868 & .000 & 8.900 & 1.615 & 5.630 & 12.170 \\
\hline
\end{tabular}

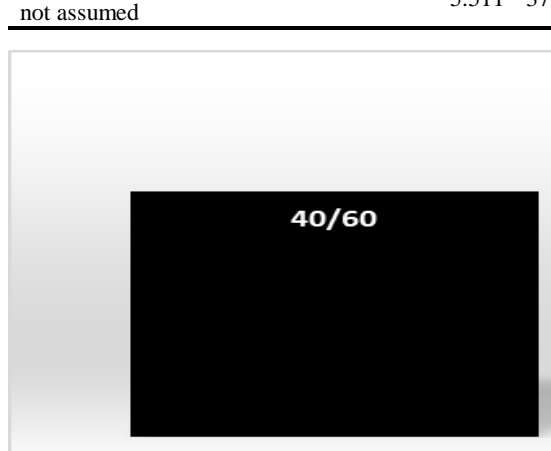

CLIL

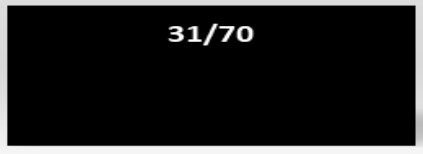

Non-CLIL

Figure 3

Means on attitude towards language learning by groups

\section{Comparing Groups' Motivation to Learn English}

An independent t-test was run to compare the CLIL and non-CLIL groups' motivation to learn English. Based on the results displayed in Table 11 it can be claimed that the CLIL group $(M=42, S D=9.45)$ were more motivated to learn English than the non-CLIL group $(M=32.60, S D=5.25)$.

Table 11

Descriptive statistics; motivation to learn English by groups

\begin{tabular}{llllll}
\hline & Group & $\mathrm{n}$ & $M$ & $S D$ & Std. Error Mean \\
\hline \multirow{2}{*}{ Motivation } & CLIL & 20 & 42.00 & 9.459 & 2.115 \\
& Non-CLIL & 20 & 32.60 & 5.256 & 1.175 \\
\hline
\end{tabular}

The results of the independent $\mathrm{t}$-test $(\mathrm{t}(29)=3.88,95 \% \mathrm{CI}[4.50,14.29], p=.000, \mathrm{r}=$ .585 representing a large effect size) (Table 12) indicated that the CLIL significantly had higher motivation to learn English than the non-CLIL group. Thus the nullhypothesis was rejected.

It should be noted that the assumption of homogeneity of variances was not retained (Levene's $\mathrm{F}=5.66, p=.022$ ). That is why the second row of Table 12, i.e. "Equal variances not assumed" was reported. 
Table 12

Independent samples t-test; motivation to learn English by groups

\begin{tabular}{|c|c|c|c|c|c|c|c|c|c|}
\hline & \multicolumn{2}{|c|}{$\begin{array}{l}\text { Levene's Test for } \\
\text { Equality of } \\
\text { Variances } \\
\end{array}$} & \multicolumn{7}{|c|}{$\mathrm{t}$-test for Equality of Means } \\
\hline & \multirow[t]{2}{*}{ F } & \multirow[t]{2}{*}{ Sig. } & \multirow[t]{2}{*}{$t$} & \multirow[t]{2}{*}{$d f$} & \multirow[t]{2}{*}{$\begin{array}{l}\text { Sig. (2- } \\
\text { tailed) }\end{array}$} & \multirow[t]{2}{*}{$\begin{array}{l}\text { Mean } \\
\text { Difference }\end{array}$} & \multirow[t]{2}{*}{$\begin{array}{l}\text { Std. Error } \\
\text { Difference }\end{array}$} & \multicolumn{2}{|c|}{$\begin{array}{l}95 \% \text { Confidence } \\
\text { Interval of the } \\
\text { Difference }\end{array}$} \\
\hline & & & & & & & & Lower & Upper \\
\hline $\begin{array}{l}\text { Equal variances } \\
\text { assumed }\end{array}$ & 5.667 & .022 & 3.885 & 38 & .000 & 9.400 & 2.420 & 4.502 & 14.298 \\
\hline $\begin{array}{l}\text { Equal variances } \\
\text { not assumed }\end{array}$ & & & 3.885 & 29.710 & .001 & 9.400 & 2.420 & 4.456 & 14.344 \\
\hline & & $2 / 00$ & & & & & & & \\
\hline & & & & & & & $32 / 60$ & & \\
\hline & & CLIL & & & & & Non-Cl & & \\
\hline
\end{tabular}

Figure 4

Means on motivation to learn English by groups

\section{DISCUSSION}

The main goal of the current study was to investigate the effect of CLIL to increase pilots' attitude and motivation which led to their English learning. For this reason, a great amount of relevant literature was reviewed to clarify the background of the study and provide an essential theoretical basis.

This study showed that since the learners presented in the CLIL class held significantly more positive attitudes towards English than those in non-CLIL class. Data analysis between these two groups revealed that use foreign language to teach content had a substantial impact on learners' attitudes. Based on this study, the atmosphere in CLIL class led to increase learners' motivation. This result confirmed a study conducted by Lasagabaster (2011), the author concluded that the CLIL approach brought positive effects to the students, both in terms of motivation and in terms of language development. The results also indicated that in CLIL class the students were more motivated to be active in comparison to other class. The students in this class were active, interested to engage, and eager to work hard in the class time. 
In CLIL class, the students were more active and had strong desire to interact with the instructor and other classmates during the class instructions, the active atmosphere in the class motivated them to be energetic, to use English for their explanation and discussion. This result could be related to a CLIL study by Gibbons (2003) that explained how science teachers interact in English with learners by providing and opening discussions to develop learners' content and language knowledge. In this study, by creating situations where teacher and students were active participants in the conversation, both linguistic and curriculum knowledge were developed. The CLIL environment raised learners' positive attitudes and motivation that led to better understanding and learning outcomes.

CLIL made a meaningful content for meaningful learning. It provided richer relation and communication situation and opportunity that engaged learners. It fostered the development of language and content learning. In this class learners found English learning easier and more attractive than non-CLIL groups, therefore, the most obvious finding to emerge from this study was that CLIL improved language learning by providing more favorable, positive attitudes and motivation towards English. It kept the learners interested in language learning. The result confirmed in a study undertaken by Varkuti (2010), the study compared CLIL students with students in an intensive language course with the same exposure times in the foreign language. Finding of this study showed that CLIL students' performance in test was higher than the other group who took part in the traditional foreign language class. Thompson and Sylvén (2015) did a research in Swedish school among students in CLIL programs and non-CLIL programs at three schools. They explored second language learning motivation as well as its impact on the language acquisition process within the context of Content and Language Integrated Learning (CLIL). The results of this study indicated that CLIL students had a greater interest in foreign languages, more positive attitudes towards learning English, a stronger ideal L2 self, more English self-confidence, and a higher willingness to communicate in English. On the other hand, non-CLIL students were more ethnocentric and had higher English anxiety. It revealed that CLIL students had a more positive attitude towards the L2 community as well as a higher intended learning effort.

These findings suggested that in general CLIL provided higher positive attitudes, increased motivation and more intense exposure, meaningful learning situation and opportunities for the learners to use foreign language as it is learned in authentic situations. The limitation of this study was paucity of the students. ICAO rule for the number of the students in aviation class is between 16 and 20, therefore, if the students will be more than this number it is better. It would be interesting to assess the effect of CLIL on students' learning in another field of the study in university or other institutes.

\section{CONCLUSION}

Prior to the present study, the method of teaching at Mahan air aviation training center was a traditional teacher-centered approach. In this approach, the instructor presented the course materials to the learners without activities and class participations and mostly in students' native language, whereas all the teaching materials and textbooks were in 
English. The impetus initiating this study was investigated the effects of CLIL on improving aviation students' attitude and motivation in the English language learning content and language in Iranian contexts.

According to the results attained in this study, CLIL class enhanced the learners' attitude, motivation, and confidence in the classroom, and also provided them a deeper knowledge of language and content related issues. This, however, can only occur if the classroom environment is learner-centered which would complement the students to think and use their cognitive awareness. The findings of this study further showed that CLIL class had significant effects on increasing motivation in the class and led to the language and subject matter learning of aviation students. According to Hall (2011), motivation could promote L2 learners. However, the present study may have important implications for material developers, course designers, and language teachers who work in the area of teaching English for Occupational Purposes (EOP).

\section{REFERENCES}

Abdelrahim, I., \& Humaida, I. (2012). Motivation to learn English among college students in Sudan. English Language Teaching, 5, 49-56.

Al-Hoorie, A. H. (2016). Unconscious motivation. Implicit attitudes toward L2 speakers. Studies in Second Language Learning and Teaching, 6, 423-454.

Bernaus, M. \& Gardner, R. C. (2008). Teacher motivation strategies, student perceptions, student motivation, and English achievement. The Modern Language Journal, 92, ii.

Brown, H. D. (2000). Principles of language learning and teaching. (4th ed.). New York: Addison Wesley Longman.

Dalton-Puffer, C., Huttner, J., Schindelegger, V., \& Smit, U. (2009). Technology-Geeks Speak Out: What Students Think About Vocational CLIL. International CLIL Research Journal, 1(2), 18-25.

Doiz, A. Lasagabaster, D. \& Juan Manuel, S. (2014). CLIL and motivation: the effect of individual and contextual cariables. The language learning journal, 42(2), 209-224.

Dornyei, Z. (2000).motivation.in M.byram (ed).Routledge encycolopedia of language teaching and learning (pp.425-4320). New York: Routledge.

Eurydice (2006). Content and Language Integrated Learning (CLIL) at school in Europe. Brussels: Eurydice European Unit.

Finegan, E. (1999). Language: Its structure and use (3th ed., p. 568). Harcourt Brace.

Gardner, R.C., \& Lambert, W.E. (1972). Attitudes and motivation in second-language learning. Rowley, Mass; Newbury House.

Gardner, R. C. (2010). Motivation and second language acquisition. The socioeducational model. New York: Peter Lang Publishing, Inc. 
Gavrilova, E., \& Trostina, K. (2014). Teaching English for professional purposes (ESP) vs. Content and language integrated learning (CLIL): The case of Plekhanov Russian University of Economic (PRUE). In: European Scientific Journal, 2, 7-17.

Gibbons, P. (2003). Mediating language learning: Teacher interactions with ESL students in a content based classroom. TESOL Quarterly, 37(2), 247-273.

Goris, J. A. (2009). English in mainstream European secondary schools: Content and language integrated learning (CLIL). In D. Marsh \& P. Mehisto (Eds.), CLIL Practice: Perspectives from the Field (pp. 28-33).

Hall, G. (2011). Exploring English Language Teaching Language in Action. London: Routledge.

Lasagabaster, D. (2011). English achievement and student motivation in CLIL and EFL settings. Innovation in Language Learning and Teaching, 5(1), 3-18.

Lorenzo, F., Casal, S., \& Moore, P. (2009). The Effects of content and language integrated learning in European education: key findings from the Andalusian bilingual sections evaluation project. Applied Linguistics, 31(3), 418-442.

Lucas. R. I. (2010). A study on intrinsic motivation factors in second language learning among selected freshman students. The Philippine ESL Journal, 4, 6-23.

Mao, Z. (2011). A study on L2 motivation and applications in reading class in senior high school. Theory and Practice in Language Studies. 1/1, 731-1739.

Marsh, D. (2000). Using languages to learn and learning to use languages. The future doesn't just happen, it is shaped and modelled by our actions. Jyvaskyla: University of Jyvaskyla.

Marsh, D. (2002): CLIL/EMILE - The European Dimension: Actions, Trends and Foresight Potential. Bruxelles: The European Union.

Nikula, T. (2017). CLIL: A European approach to bilingual education. Learning evidence from research in Europe, 22-40. Bristol: Multilingual Matters.

Ruiz de Zarobe, Y. (2008). CLIL and foreign language learning: A longitudinal study in the Basque country. International CLIL Research Journal, 1(1), 60-73.

Stansfield, C., \& Winke, P. (2008). Testing aptitude for second language learning. In E.

Shohamy, \& N. H. Hornberger (Eds.), Encyclopedia of Language and Education, 2nd edition, 7: Language Testing and Assessment (pp. 81-94)

Thompson, A. S. \& Sylvén, L. K. (2015). “Does English make you nervous?” Anxiety profiles of CLIL and non-CLIL students in Sweden. Apples: journal of applied language studies, 9(2), 1-23.

Tuan, L. (2012). An empirical research into EFL learners' motivation. Theory and Practice in Language Studies, 2, 430-439. 
Varkuti, A. (2010). Linguistic benefits of the CLIL approach: Measuring linguistic competences. International CLIL Research Journal, 1(3), 67-79.

Wolff, D. (2009). Content and language integrated learning. In: Knapp, Karlfied, Seidlhofer, Barbara (Eds.): Handbook of Foreign Language Communication and Learning. Berlin: Walter de Gruyter, 545-572. 